\title{
PENGARUH PARTISIPASI PENYUSUNAN ANGGARAN TERHADAP KEPUASAN KERJA DAN KINERJA KARYAWAN DENGAN JOB RELEVANT INFORMATION SEBAGAI VARIABEL INTERVENING (STUDI EMPIRIS PADA PT. ALBASIA BHUMIPHALA PERSADA TEMANGGUNG)
}

\author{
Susi Sih Kusumawardhany \\ Universitas Pamulang \\ email : sskusumawardhany@gmail.com
}

Paper Accepted: 22 Juni 2018 Paper Reviewed: 7-15 Juli 2018 Paper Edited: 17-24 Juli 2018 Paper Approved: 25 Juli 2018

\begin{abstract}
Recently a company faced by a very rapid changing and competitive environment. In order to win the competition, a company must increase their performance. Business globalization evoke continuously changing in all business aspect so an alteration became a normal condition. On of the management tool that often used by the management to manage their company is budget. Budget can be used by management as tool to plan and control the company activity. The purpose of the research is to examine the relationship between participative budget with job satisfaction and employee's performanceand also the role of Job Relevant Information (JRI) as the intervening variable between participative budget with job satisfaction and employee's performance. Variable that is used this research is participant budget, job satisfaction, employee's performance and job relevant information (JRI). This research using survey method in which the researcher distribute questionnaire which include list of question to chosen respondents. Data analyses that were used in this research are validity and realibility test, Structural Equation Model and path analysis. The result shows that relationship between participative budget and job satisfaction figure out that participation in budgetary has positie in direct effect on employee's job satisfaction and relationship between participative budget and job performance figure out that participation in budgetary has positive in direct effect on employee's job performance. In addition, the relationship between participative budgetary and job satisfaction through job relevant information as an intervening variable shows that there is a significantly positive direct effect., while the relationship between participative budgetary a job performance through job relevant information as an intervening variable shows that there is a significantly positive direct effect.
\end{abstract}

Keywords: participative budgetary, job satisfaction, job performance and job relevant information.

\section{PENDAHULUAN}

Di era globalisasi ini telah menuntut adanya perubahan yang sangat cepat dan menyebabkan adanya pergeseran pemikiran yang kompleks disegala bidang. Untuk itu perusahaan harus memiliki keunggulan yang kompetitif agar dapat memenangkan persaingan, minimal untuk mempertahankan operasi perusahaan. Salah satu keunggulan 
kompetitif yang penting bagi perusahaan adalah karyawan perusahaan. Karyawan perusahaan merupakan penggerak operasi perusahaan, sehingga jika kinerja karyawan perusahaan baik, maka kinerja perusahaan juga akan meningkat. Dalam rangka memberikan pelayanan yang lebih baik kepada masyarakat, maka karyawan dituntut dapat meningkatkan kinerja. Kinerja para karyawan akan meningkat apabila mereka terlibat secara aktif dalam proses penyusunan anggaran pada unit organisasi dimana mereka bekerja.

Dengan adanya partisipasi karyawan dalam penyusunan anggaran, hal ini akan meningkatkan kesadaran karyawan akan tugas dan tanggung jawab yang dibebankan kepadanya dan karyawan tahu benar mengenai apa yang dikerjakan berkaitan dengan pencapaian anggaran. Dalam proses penyusunan anggaran akan berpengaruh terhadap kinerja karyawan. Dengan dilibatkannya karyawan dalam proses penyusunan anggaran, hal ini akan menimbulkan komitmen pada karyawan bahwa anggaran yang ada juga merupakan tujuannya.

Anggaran merukan implementasi dari rencana yang efektif dalam jangka pendek dan untuk proses pengendalian dalam organisasi. Anggararan juga merupakan proses pengendalian manajemen yang melibatkan komunikasi dan interaksi formal dikalangan para manajer dan karyawan yang merupakan pengendalian manajemen atas operasional perushaan pada tahun yang berjalan.program atau strategi plan yang telah disetujui pada tahap sebelumnya, merupakan titik awal dalam mempersiapkan anggaran. Efektifitas proses dan pelaksanaan anggaran akan terwujud bila didukung oleh pihak yang berkepentingan baik manajer atau karyawan. Anggaran menunjukkan jabaran dari program dengan menggunakan informasi terkini. Para manajer dan karyawan secara bersama-sama mempunyai kepentingan terhadap pencapaian tujuan anggaran. Anggaran juga merupakan alat manajemen untuk melakukan pengendalian, koordinasi, komunikasi, penilaian kinerja dan motivasi (Sinurya, 2008). Oleh karena anggaran merupakan dasar pengukuran kinerja bagi manajer, maka anggaran operasi biasanya meliputi satu tahun dan dinyatakan pendapat serta biaya yang direncanakan pada tahun tersebut (Anthony dan Govindarajan, 2003).

Anggaran dapat dikatakan sebagai alat untuk mengoperasikan tujuan yang akan dicapai dalam jangka pendek. Dengan demikian anggaran memformulasikan target prestasi yang harapan. Target ini secara langsung dapat membantu kegiatan organisasi, mengindentifikasi masalah, membantu memotivasi karyawan tingkat bawah dan menjelaskan hubungan aktivitas yang berlangsung dengan kebijaksanaan masa yang akan dating. Kondisi ini secara eksplisit juga menyatukan kontribusi penyusunan anggaran adalah perencanaan pengendalian manajerial. Anggaran merupakan komponen penting dalam perusahaan. Pentingnya fungsi anggaran sebagai perencanaan dan pengendali perusahaan yang menjadikan penganggaran sebagai masalah penting bagi keberhasilan anggaran perusahaan. Anggaran memiliki dampak langsung terhadap perilaku manusia. Orang-orang merasakan tekanan dari anggaran yang ketat dan kegelisahaan atas laporan kinerja yang buruk sehingga sering kali dipandang sebagai penghalang kemajuan karier mereka.

Penyusunan anggaran dapat dilakukan dengan pendekatan bottom up atau top down (Rosidi,2000). Perkembangan saat ini bahwa penyusunan anggaran dilakukan dengan pendekatan partisipasi antara atasan dan bawahan. Penyusunan anggaran dengan partisipasi ini memungkinkan adanya negoisasi antara manajer sebagai atasan dengan karyawan sebagai bawahan. Rosidi (2000) menyatakan bahwa partisipasi manager menengah dan bawah partisipasi manajer menengah dalam penyusunan anggaran akan memberikan manfaat, antara lain:

1. Mengurangi ketimpangan informasi dalam organisai

2. Menimbulkan komitmen yang lebih besar kepada manajer untuk melaksanakan dan memenuhi anggaran.

Banyak penelitian bidang akuntansi manajemen yang menaruh perhatian pada masalah partisipasi anggaran, hal ini karena partisipasi anggaran dinilai mempunyai konsekuensi terhadapa sikap dan perilaku anggota organisasi. Sinuraya (2008) menyebutkan dua alasan penelin ini menjadi menarik, yaitu:
1. Partisipasi anggaran dinilai Sebagai pendekatan managerial yang dapat meningkatkan kinerja anggota dalam organisasi.

2. Berbagai penelitian yang menguji hubungan antara partisipasi dan kinerja hasilnya saling bertentangan.

Peneliatian Supriyono (2004) melihat hubungan partisipasi pengganggaran dan kinerja dengan variabel intervening kecukupan anggaran dan komitmen organisasi. Sampel penelitian ini adalah direktur utama perusahaan go public yang terdaftar pada Capital Market Directory 2001 yang menimpulkan bahwa: 
1. Partisipasi penanggaran dan kinerja manajer mempunyai hubungan positif signifikan.

2. Partisipasi penanggaran dan kecukupan anggaran mempunyai hubungan positif signifikan.

3. Partipasi penanggaran dan komitmen organisasi mempunyai hubungan positif signifikan.

4. Kecukupan anggaran dan komitmen organisasi mempunyai hubungan positif yang siginifikan.

5. Kecukupan dan kinerja manager memiliki hubungan positif yang tidak signifikan.

Penelitian Indiarto dan Supomo (2002) menyatakan bahwa variabel intervening merupakan variabel yang terletak diantara varibel-variabel independen dengan varibelvaribel dependen, sehingga varibel independen tidak langsung menjelaskan atau mempengaruhi varibel dependen. Dalam penelitian tersebut digunakan untuk mengevaluasi hubungan antara partisipasi anggaran dengan kinerja, digunakan dua varibel intervening yaitu kecukupan anggaran dan job relevant information. Penelitian tersebut mengkonfirmasi hubungan antara partisipasi pengganggaran dengan kinerja manajer dengan memilih kecukupan anggaran dan job relevant information Sebagai varibel intervening.

Partisipasi anggran adalah luasnya pengaruh dan keterlibatan manajer dan bawahan dalam penyusunan anggaran. Kinerja manajer merupakan kemampuan manajer dalam melaksanakan tanggungjawabnya terhadap kualitas produk, kuantitas produk, ketepatan waktu produk, pengembangan produk baru, pengembangan personel, pencapaian anggaran, pegurangan biaya (peningkatan pendapatan) dan urusan publik. Job relevant Information diidentifikasi sebagai salah satu informasi yang membantu manajer untuk memperbaiki pemilihan tindakannya melalui upaya yang diinformasikan dengan baik, baik yang bersumber dari lingkungan eksternal atau internal perusahaan. Selain informasi yang mempengaruhi keputusan (Sinurya, 2008). Job relevant information dapat memperbaiki kinerja karena memberikan pilihan yang lebih efektif untuk melakukan tindakan terbaik.

Dengan demikian penulis ingin meneliti mengenai "Pengaruh partisipasi dalam peyusunan anggaran terhadap kepuasan kerja dan kinerja karyawan dengan Job relevant information (JRI) Sebagai variabel Intervening".

\section{KERANGKA TEORITIS DAN PENGEMBANGAN HIPOTESIS Pengertian Anggaran}

Anggaran merupakan pernyataan formal yang dibuat oleh manajemen tentang pelaksanaan rencana-rencana masa akan datang pada periode tertentu. Anggaran juga digunakan Sebagai pedoman dalam pelaksanaan kegiatan selama periode tersebut. Ada dua tujuan yang ingin dicapai dari anggaran yaitu untuk mendorong motivasi kinerja bawahan dan Sebagai alat perencanaan.

\section{Partisipasi dalam Proses Penyusunan Anggaran dan Job Relevant Information (JRI)}

Partisipasi merupakan proses kerja sama dalam pengambilan keputusan antara dua kelompok atau lebih yang berpengaruh pada pengambilan keputusan yang berpengaruh dimasa yang akan datang. Dengan kata lain karyawan dan manajer tingkat bawah mempunyai andil dalam pengambilan keputusan. Para manajer bawah sebenarnya memiliki informasi yang lebih baik dibandingkan yang dimiliki manager atas. Pada sebagian besar organisasi, para manajer tingkat menengah ke bawah lebih banyak memiliki informasi yang akurat dibandingkan diatasnya. Sementara pada sisi lain, manajer tingkat atas yang lebih dominan dalam posisinya akan merasa lebih mampu menyusun anggaran karena adanya perbedaan status ini memunculkan kendala partisipasi. Untuk menghilangkan atau meminimalisasikan terjadinya perbedaan persepsi pada kedua tingkatan manajer ini, serta memaksimalkan partisipasi agar menjadi efektif, maka manager bawah ditingkat organisasi harus diberi kesempatan untuk memberikan pendapat dalam proses penyusunan anggaran dengan mengungkapkan informasi yang dimiliki terkait pekerjaan sebagai kontribusi dalam penetapan jumlah anggaran.

\section{Kepuasan kerja}

Kepuasan kerja (job statisfication) Sebagai suatu sikap umum seorang individu terhadap pekerjaannya. Seorang dengan tingkat kepuasaan tinggi menunjukkan sikap yang positif terhadap kerja itu, seseorang yang tidak puas dengan pekerjaannya menunjukkan sikap yang negatif terhadap pekerjaan itu. Kepuasan kerja merupakan hal yang bersifat individual. Setiap individu memiliki tingakat kepuasan 
yang berbeda-beda sesuai dengan sistem yang berlaku pada dirinya. Ada 4 pendekatan teoritis yang membahas mengenai kepuasan kerja yaitu : Fulfillment theory, Equity theory, Discrepancy theory dan Two factor theory.

\section{Kinerja Karyawan}

Dalam proses penyusunan anggaran, partisipasi karyawan akan berpengaruh terhadap kinerja karyawan. Kinerja karyawan adalah individu anggota organisasi dalam kegiatankegiatan operasional, antara lain: perencanaan, investigasi, pengkordinasi, supervise, pengaturan staf (staffing), negoisasi dan representasi serta satu pengukuran secara keseluruhan. Dengan dilibatkannya karyawan dalam proses penyusunan anggaran, hal ini akan menimbulkan komitmen pada karyawan bahwa anggaran yang ada juga merupakan tujuannya. Tujuan penyusunan anggaran antara lain mengkomunikasikan tujuan dan metode yang ditetapkan oleh manajemen puncak. Penyusuanan anggaran yang berhubungan dengan kebijakan dan tujuan fundamental dipersiapkan oleh manajemen puncak. Dengan adanya komunikasi antara atasan dan bawahan (karyawan) sangat besar pengaruhnya terhadap motivasi karyawan dalam bekerja. Dengan demikian pula dengan seorang atasan selain harus memperhatikan kebutuhan-kebutuhan karyawan yang mendorong motivasi, juga harus menciptakan komunikasi ke atas yang baik dengan karyawan. Komunikasi keatas ini sangat besar pengaruhnya terhadap motivasi karyawan dalam bekerja.

\section{Job Relevant Information}

Job relevant information adalah informasi yang tersedia bagi manajer untuk meningkatkan efektifitas pengambilan keputusan yang berkaitan dengan tugas atau informasi yang memfasilitasi pengambilan keputusan yang berkaitan dengan tugas. Proses penyusunan anggaran bisa dari atas ke bawah atau sebaliknya yang paling penting disini adalah komunikasi dan indormasi yang akurat terkait dengan penyusunan anggaran. Ada tiga macam pendekatan untuk menyusun anggaran yaitu pendekatan dari atas kebawah (Top down approach), pendekatan dari bawah ke atas (Bottom up approach) dan partisipasi anggaran (Participative budget).

\section{Penelitian Terdahulu dan Pengembangan Hipotesis}

Berikut ini, beberapa penelitian terdahulu mengenai pengaruh faktor-faktor yang berkaitan dengan partisipasi penyusunan anggaran, kepuasan kerja, kinerja karyawan dengan job relevant information serta pengembangan hipotesis.

\section{Hubungan Partisipasi Anggaran terhadap Kepuasan Kerja dan Kinerja Karyawan}

Kinerja karyawan yang diperoleh oleh manajer merupakan salah satu faktor yang dapat dipakai untuk meningkatkan efektifitas organisasi (Riyadi, 2000). Dikutip dari Sinurya (2008) kinerja manajer adalah kinerja individu anggota organisasi dalam kegiatan-kegiatan manajerial, antara lain: perencanaan, investigasi, koordinasi, supervise, pengaturan staf (staffing), negoisasi dan representasi. Untuk itu membutuhkan karyawan untuk terlibat menjadi anggota tim perencanaan anggaran bersama manajemen. Setiap anggota tim telah dibekali akuntabilitas untuk perencanaan, pengawasan dan koordinasi kinerja panganggaran.

Abriani (1998) dalam Sinurya, 2008 membuktikan pengaruh partisipasi dalam penyusunan anggaran terhadap kepuasan kerja dan kinerja manajer dengan role ambiguity Sebagai varibel antara. Subyek penelian dilakukan terhadap manajer perusahaan manufaktur besar di pulau jawa. Dalam penelitian ini ditemukan hubungan positif yang menunjukkan hubungan searah antara partisipasi dengan kepuasan kerja, sehingga dapat dinyatakan bahwa semakin tinggi partisipasi dalam penyusunan anggaran maka akan semakin tinggi kepuasan kerja, selain itu ditemukan juga hubungan positif yang menunjukkan hubungan searah antara partisipasi dengan kinerja manajer, sehingga dapat dinyatakan bahwa semakin tinggi partisipasi penyusunan anggaran maka semakin tinggi kinerja manajer.

Penetapan penyusunan anggaran pada awal kegiatan mengharuskan semua anggota organisasi mengarahkan segala kegiatan sesuai tujuan yang telah ditetapkan. Manajemen pada fungsi perencanaan dalam hal ini dituntut untuk memperhatikan penggunaan sumber-sumber ekonomi yang efisien. Dalam keterlibatan tersebut, para manajer dan karyawan mengetahui seberapa besar kemampuan yang dimilikinya dalam pencapaian target selain itu juga menimbulkan rasa dihargai dan dipercaya yang mengakibatkan rasa kepuasan atas pekerjaanya. Partisipasi bawahan dalam penyusunan anggaran dan peran anggaran sebagai pengukur kinerja memiliki kaitan yang cukup erat. Partisipasi anggaran berhubungan dengan luasnya keterlibatan karyawan dan memiliki pengaruh dalam penentuan anggaran 
yang akhirnya akan dievaluasi dan dihargai atas pencapaian target yang ditetapkan.

Berdasarkan uraian diatas, peneliti bermaksud untuk menguji hubungan partisipasi anggaran terhadap kepuasan kerja dan kinerja karyawan dengan hipotesis sebagai berikut:

$\mathrm{H} 1$ : Partisipasi penyusunan anggaran berpengaruh positif terhadap kepuasan kerja.

H2 : Partisipasi penyusunan anggaran berpengaruh positif terhadap kinerja karyawan.

\section{Hubungan Partisipasi Anggaran terhadap Job Relevant Information}

Penelitian Kren (1992) dalam Sinurya, 2008 menggunakan variabel informasi yang berhubungan dengan tugas (job relevant information) sebagai variabel intervening dan ditemukan bukti bahwa partisipasi anggaran tidak berhubungan secara langsung dengan kinerja manajer akan tetapi melalui job relevant information. Penelitian tersebut menemukan adanya hubungan positif antara Job relevant information dengan kinerja yaitu job relevant information akan meningkatkan kinerja manajer karena informasi tersebut dapat membantu manajer dalam memprediksikan lingkungan yang dihadapi dengan lebih tepat dan memungkinkan manajer untuk memilih peluang dengan lebih efektif.

Dalam proses partisipasi, bawahan diberi kesempatan untuk memberikan masukan berupa informasi yang dimilikinya kepada atasan sehingga atasan akan memperoleh pemahaman yang lebih baik tentang pengetahuan yang relevan dengan tugas (task relevant knowledge) Yusfaningrum dan ghozali, 2008. Informasi yang dihasilkan dalam proses penetapan anggaran ini, berguna untuk merencanakan anggaran yang lebih realistis dan lebih akurat, terutama informasi yang berhubungan dengan pekerjaannya.

Penelitian Chong dan Chong (2002) dalan Sinurya, 2008 menyebutkan adanya peran komitmen dan informasi terhadap kinerja manajer. Job relevant information dapat membantu manajer dalam memperbaiki tindakannya dengan adanya informasi yang lebih akurat sehingga anggaran yang ditetapkan lebih realistis, sebab informasi tersebut dapat memprediksi lingkungan dengan lebih tepat dan mumungkinkan pemilihan suatu kesempatan yang lebih efektif. Penelitian tersebut mendukung bahwa partisipasi menciptakan kesempatan bagi bawahan untuk memperoleh dan menyebarkan informasi relevan yang dapat memfasilitasi proses pengambilan keputusan mereka. Berkaitan dengan partisipasi penganggaran maka job relevant information memfasilitasi selama proses anggaran. Ketika mempersiapkan anggaran secara partisipasi, manajer secara umum memberikan peran aktif yang mana terlihat mempertimbangkan dan mengevaluasi alternatif tujuan dari anggaran. Konsekuensinya, partisipasi anggaran menciptakan suatu lingkungan yang mendorong perolehan dan penggunaan job relevant information.

Jadi, partisipasi penganggaran menumbuhkan motivasi dalam diri manajer untuk memperoleh dan menggunakan informasi yang terbaik untuk dihunakan Sebagai dasar pengambilan keputusan anggaran, sehingga dalam hal ini m,anajer akan berpartisipasi untuk memperoleh dan menggunakan informasi yang relevan dalam rangka pengambilan keputusan yang lebih akurat. Maka, berdasarkan hal tersebut diajukan hipotesis sebagai berikut:

H3 : Partisipasi penyusunan anggaran berpengaruh positif terhadap job relevant information.

\section{Hubungan Partisipasi Penyusunan Anggaran terhadap Kepuasan Kerja dan Kinerja Karyawan melalui variabel intervening $\mathbf{J o b}$ Relevant Information.}

Menurut Kren (1992) dalam Sinurya , 2008 menyatakan job relevant information mempengaruhi kinerja karena memberikan prediksi yang akurat atas kondisi lingkungan dan memberikan seleksi yang lebih efektif untuk melakukan tindakan yang terbaik. Penelian Chong dan Chong (2002) dalam Sinurya, 2008 juga mendukung bahwa partisipasi anggaran menciptakan kesempatan bagi bawahan untuk memperoleh dan menyebarkan informasi yang relevan dan dapat memfasilitasi proses pembuatan keputusan sehingga dengan informasi yang relevan akan meningkatkan kinerja.

Marsudi dan Ghozali (2001) meneliti Pengaruh partisipasi anggaran, job relevant information dan Volatilitas lingkungan terhadap kinerja manajerial pada perusahaan manufaktur di Indonesia. Popolasi penelitian ini menggunakan manajer-manajer fungsional yang bekerja minimal lima tahun sebagai unit analisis. Untuk menentukan sampel penelitian menggunakan perusahaan-perusahaan manufaktur terdaftar di Bursa Efek Jakarta yang dimuat dalam Indonesian Capital Market Directory 2000 sebagai rerangka sampling. Penelitian ini berhasil membuktikan bahwa job relevant information merupakan variabel intervening antara partisipasi penganggaran dan 
kinerja manajerial. Hal ini mengidentifikasi bahwa manajer menggunakan partisipasi sebagai alat yang efisien untuk memperoleh informasi yang berhubungan dengan tugas.

Penelitian Siegers (2003) dalam Sinurya, 2008 meneliti hubungan partisipasi anggaran dengan job relevant information serta pengaruhnya terhadap kepuasan kerja dan kinerja manajerial di lingkungan pemerintah Daerah Istimewa Yogyakarta. Dalam penelitian ini ditemukan bahwa hubungan tidak langsung antara partisipasi anggaran dengan keputusan kerja yang dimediasi informasi menunjukkan ada pengaruh positif dan signifikan. Begitu pula hubungan tidak langsung antara partisipasi anggaran dengan kinerja karyawan yang dimediasi informasi menunjukkan ada pengaruh positif dan signifikan. Dari uraian diatas maka diajukan hipotesis sebagai berikut:
H4 : Partisipasi penyusunan anggaran berpengaruh positif terhadap kepuasan kerja secara tidak langsung melalui variabel intervening yaitu job relevant information.

H5 : Partisipasi penyusunan anggaran berpengaruh positif terhadap kinerja karyawan secara tidak langsung melalui variabel intervening yaitu job relevant information.

\section{MODEL PENELITIAN}

Hubungan hipotesis penelitian dengan menggunakan analisi jalur (path analysis) ini secara umum model penelitian ini dapat digambarkan seperti dibawah ini:

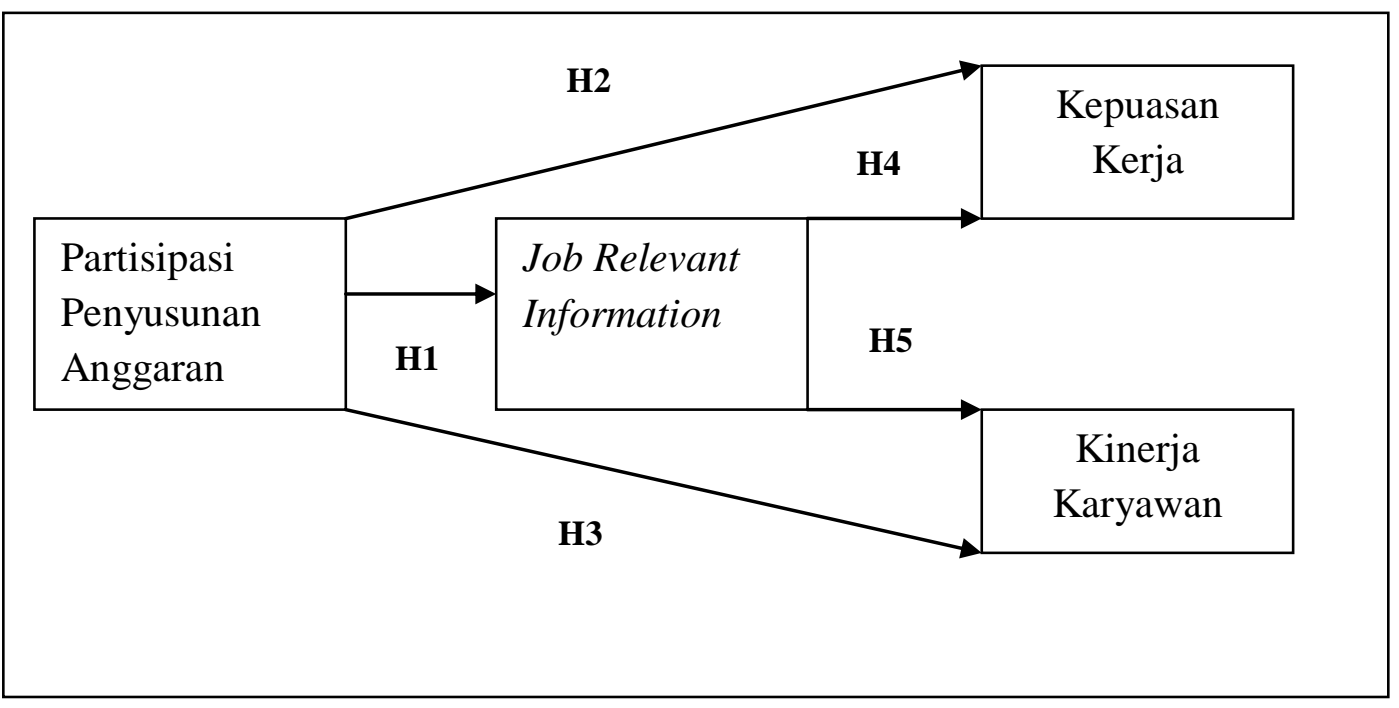

Gambar 1.1

Skema Jalur Penelitian

Skema analisis jalur ini menunjukkan bahwa partisipasi penyusunan anggaran berpengaruh terhadap kepuasan kerja dan kinerja karyawan melalui variabel intervening yaitu job relevant information.

\section{METODE PENELITIAN \\ Pemilihan Sampel}

Penelitian ini merupakan penelitian yang dirancang untuk menguji hubungan partisipasi anggaran dan job relevant information serta pengaruhnya terhadap kepuasan kerja dan kinerja karyawan di lingkungan perusahaan.
Responden dalam penelitian ini adalah karyawan PT. Albasia Bhumiphala Persada di Temanggung dari level bawah ke atas dengan populasi karyawan sebanyak 150 orang.

Pemilihan sampel dengan cara purposive sampling yaitu pemilihan sampel yang sesuai dengan tujuan penelitian dan juga menggunakan metode survey yaitu penyelidikan yang diadakan untuk memperoleh fakta-fakta dalam perusahaan. Penelitian ini difokuskan untuk mengetahui faktor-faktor yang terkait dengan partisipasi penyusunan anggaran, kepuasan kerja, kinerja karyawan dan job relevant information. Dipilihnya perusahaan ini sebagai 
responden dengan pertimbangan bahwa proses penyusunan anggaran pada perusahaan ini lebih kompleks dibanding jasa dan pemilihan sampel pada salah satu industri akan mengurangi industry effect terhadap data yang akan dianalisis.

\section{Pengumpulan Data}

Data yang digunakan dalam penelitian ini adalah data primer dan data sekunder. Data primer berupa persepsi para responden terhadap variabel-variabel yang digunakan. Modus komunikasi untuk memperoleh data dari responden dalam penelitian ini menggunakan kuesioner. Pengumpulan data dilakukan dengan menggunakan metode distribusi langsung (direct distribution method) yaitu mendatangi para responden secara langsung untuk menyerahkan dan mengumpulkan kembali kuesioner.kuesioner terdiri dari 2 bagian,yaitu:

1. Berisikan pertanyaan-pertanyaan tentang demografi responden.

2. Berisikan pertanyaan-pertanyaan data yang berkaitan dengan variabel penelitian.

Setiap kuesioner yang didistribusikan kepada para responden disertai surat pemohonan pengisian kuesioner. Dalam surat pemohonan pengisian dinyatakan identitas penelitian, tujuan penelitian dan pemotivasi responden untuk mengisi kuesioner secara lengkap serta jaminan atas kerahasiaan responden. Disamping data primer, dalam penelitian ini juga diperlukan data sekunder yaitu data yang diperoleh dari sumber dokumen perusahaan.

\section{Definisi dan pengukuran variabel \\ Partisipasi penyusunan Anggaran}

Partisipasi penyusunan anggaran adalah berhubungan dengan luasnya keterlibatan dan memiliki pengaruh dalam penentuan anggaran yang kinerjanya yang akan dievaluasi dan dihargai atas pencapaian target anggaran mereka. Penilaian desain menggunakan skala Likert dengan alternatif jawaban dari satu (sangat rendah) sampai dengan lima (sangat tinggi).

\section{Kepuasan Kerja}

Variabel kepuasan kerja diukur menggunakan instrument yang dikembangkan dari Minnesotta Satisfaction Questionare (MSQ) untuk mengukur kepuasan kerja berdasarkan berbagai dimensi pekerjaan. Seperti kompensasi penyedia, kondisi kerja, variasi tugas, tingkat tanggungjawab dan kesempatan- kesempatan yang diberikan untuk kemajuan individu organisasi. Masing-masing item menggunakan skala Likert dengan alternatif jawaban dari satu (sangat tidak setuju) sampai dengan lima (sangat setuju).

\section{Kinerja Karyawan}

Kinerja karyawan adalah kinerja individu anggota organisasi dalam kegiatan-kegiatan operasional, antara lain: perencanaan, investigasi, pengkoordinasi, supervise, pengaturan staf (staffing), negoisasi dan reputasi serta satu pengukuran secara keseluruhan. Sebagai konsekuensinya dalam mengevaluasi kinerja unit bisnis dan pusat-pusat pertanggungjawaban digunakan berbagai ukuran untuk membandingkan ekspektasi sebelumnya dengan kinerja sesungguhnya. Penilaian desain menggunakan skala Likert dengan alternatif jawaban dari satu (sangat rendah) sampai dengan lima (sangat tinggi). Sehingga alternatif satu berarti sangat rendah dengan lima sangat tinggi kinerjanya.

\section{Job Relevant Information}

$J o b$ relevant information adalah informasi yang tersedia bagi manajer untuk meningkatkan efektifitas pengambilan keputusan yang berkaitan dengan tugas atau informasi yang memfasilitasi pengambilan keputusan yang berkaitan dengan tugas. Pengukuran variabel job relevant information menggunakan instrument O'Relly yang dikembangkan oleh Kren (1992) dalam Sinuraya, 2008 yang kemudian dikembangkan oleh Vebyana (2003). Penilaian desain menggunakan skala Likert dengan alternatif jawaban dari satu (sangat rendah) sampai dengan lima (sangat tinggi).

\section{Pengujian Validitas dan Reabilitas}

Analisis dimulai dengan pengujian validitas terlebih dahulu dan kemudian diikuti dengan pengujian reabilitas. Pengujian validitas dilakukan dengan menggunakan analisis faktor dimaksud untuk memastikan masing-masing instrument akan merefleksikan konstruk yang ditentukan (contruct validity). Uji analisis faktor terhadap setiap variabel yang dilakukan satu persatu dengan varimax rotation.

Suatu data dapat dilakukan analisis faktor apabila nilai Kaiser Mayer Olkin Measure of Sampling Adequacy (Kaiser MSA) diatas 0,50 (Kaiser dan Rice, 1974 dalam Riyadi, 2002). Selanjutnya uji validitas dilakukan dengan menggunakan factor loading. Hari dkk (1998) dalam Sinurya, 2008 
memberikan kriteria sebagai berikut: factor loading yang lebih besar dari 0,30 adalah signifikan, factor loading yang lebih besar dari 0,40 adalah signifikan dan factor loading yang lebih besar dari 0,50 adalah tergolong sangat signifikan.

\section{Pengujian Hipotesis}

Pengujian hipotesis yang dilakukan dalam penelitian ini adalah menggunakan Structure Equation Model (SEM), yang memberikan pengujian terhadap hubungan dependen secara simultan (Hair dkk, 1995 dalam Sinurya, 2008). Penelitian SEM berguna untuk penelitian yang dilakukan terhadap hubungan variabel dependen terhadap variabel independen, dimana variabel dependen juga berkedudukan menjadi variabel independen pada hubungan yang lain. Analisis SEM yang akan direncanakan digunakan untuk menguji ke lima hipotesis dalam penelitian ini. Dalam pengujian tersebut harus dapat memenuhi tahap-tahap pemenuhan SEM antara lain: analisis normalitas, Multivariate outliers, Multicollinearity dan Singulary, evaluasi kriteria Goodness of Fit dan analisis atas Full Structural Equation Model.

Untuk menguji seluruh hipotesis yang diajukan, hubungan langsung dan tak langsung diantara variabel-variabel yang diuji dan peran relative masing-masing variabel independen dalam mempengaruhi variabel dependen, maka akan dilakukan pengujian keseluruhan hubungan variabel dengan menggunakan analisis Structure Equation Model (SEM). Semua hipotesis dalam studi ini diuji dengan path analysis. Cara yang ditempuh adalah dengan membandingkan nilai critical ratio (CR) dan nilai t pada degree of freedom (df) tertentu atau dengan membandingkan nilai $\mathrm{CR}$ pada probabilitas hitung dengan probabilitas kritis $(\mathrm{P}>0,05$ atau $\mathrm{P}<0,001)$.

Path analysis digunakan untuk melakukan penilaian terhadap berbagai kriteria kesesuaian model dan untuk menguji kelima hipotesis dalam penelitian ini. Goodness of fit mengukur kesesuaian input observasi dengan prediksi model yang diajukan. Dapat disimpulkan hasil pengujiannya bahwa sebagian besar kriteria yang digunakan memiliki kesesuaian yang memadai, sehingga model yang digunakan adalah mengkonfirmasi hasil antara kesesuaian teoritis dan pengujian secara empirik.

\section{HASIL PENELITIAN DAN PEMBAHASAN}

\section{Analisis Deskriptif}

Dari penyebaran kuesioner yang dilakukan sebanyak 150 yang disebar yang dikembalikan 120 kuesioner. Dari 120 kuesioner yang kembali hanya 115 yang dapat diolah dan terdapat sekitar 83 orang $(72 \%)$ responden pria serta 32 oeang (28\%) responden wanita. Pendidikan responden terbanyak adalah S1 sebesar 80 orang $(70 \%)$, D3 sebesar 30 orang $(26 \%)$ dan pendidkan S2 sebesar 5 orang $(4 \%)$. Dilihat dari lamanya responden bekerja di PT.Albasia Bhumiphala Persada kurang dari 5 tahun sebanayak 27 orang (23\%) dan lebih dari 5 tahun samapai dengan 10 tahun sebanyak 88 orang $(77 \%)$.

\section{Analisis Kualitas Data}

Dari hasil uji kualitas data terdapat hasil validitas dan realibilitas. Untuk uji validitas dari keempat instrument didapat valid, hal ini ditunjukkan dengan hasil factor loading diatas kisaran 0,40 (Hair dkk,1998 dalam Sinurya, 2008). Sedangkan Uji realibilitas adalah suatu pengukuran mencerminkan suatu data dapat terbebas dari kesalahan, sehingga memberikan hasil pengukuran yang konsisten internal pada kondisi yang berbeda pada masing-masing butir dalam instrument yang diukur dengan factor loading dari hasil analisis Cronbach's Alpha dengan nilai lebih besar dari 0,60.

Hasil dari pengujian validitas dan reliabilitas dapat dilihat dari tabel berikut:

Tabel Hasil Uji Validitas dan Reliabilitas

\begin{tabular}{|l|c|c|}
\hline \multicolumn{1}{|c|}{ Variabel } & Validitas & Reliabilitas \\
\hline Partisipasi Penyusunan anggaran & $0.657-0,830$ & 0,851 \\
\hline Job Relevant Information & $0,739-0,874$ & 0,789 \\
\hline Kepuasan Kerja & $0,591-0,893$ & 0,972 \\
\hline Kinerja Karyawan & $0,712-0,887$ & 0,943 \\
\hline
\end{tabular}

Analisis Model Struktural Pengujian Normalitas
Salah satu syarat menggunakan model SEM adalah mengevaluasi normalitas dan data 
univariate dan multivariate. Tujuannya untuk mengidentifikasi normalitas sebaran data dengan menggunakan nilai pada tabel normalitas dengan nilai critical ratio (CR) dengan tingkat signifikansi 0,05 yaitu sebesar $\pm 1,96$ atau tingkat signifikansi 0,10 yaitu sebesar $\pm 2,58$. Jika nilai critical ratio yang dihasilkan oleh masing-masing variabel lebih kecil atau sama dengan 1,96 atau 2,58 maka distribusi data bersifat normal. Dari hasil uji normalitas didapat nilai critical ratio lebih kecil dari nilai standar yaitu dari nilai -1,676 sampai dengan 1,288 sehingga hasil dari uji normalitas data dapat terpenuhi data bersifat normal.

\section{Pengujian Multivariate Outliers}

Outliers adalah observasi yang muncul dengan nilai ekstrim secara multivariate yaitu muncul karena kombinasi karakteristik unik yang dimilikinya dan terlihat sangat jauh berbeda dari variabel lainnya. Deteksi multivariate outliers dilakukan dengan membandingkan tabel output hasil komputasi yang ditunjukkan melalui mahalanobis distance pada level signifikansi $(\mathrm{p}<0,05)$ terhadap nilai chi-square $\left(\mathrm{X}^{2}\right)$ pada degree of freedom $(\mathrm{df})$ sebesar jumlah multivariate yaitu muncul karena kombinasi karakteristik unik yang dimilikinya dan terlihat sangat jauh berbeda dari variabel lainnya. Deteksi multivariate outliers dilakukan dengan membandingkan tabel output hasil komputasi yang ditunjukkan melalui nilai mahalonobis distance pada level signifikansi $(\mathrm{p}<0,05)$ terhadap nilai chi square $\left(\mathrm{X}^{2}\right)$ pada degree of freedom (df) sebesar jumlah variabel. Jika observasi memiliki nilai mahalanobis distance squared, maka diidentifikasi Sebagai multivariate outliers. Hasil uji multivariate outliers secara lengkap ditunjukkan pada structural equation modeling.

Pengujian asumsi ini dapat diidentifikasi melalui nilai determinant of sample covariance matrix. Jikan nilai determinan lebih besar dari 0 (nol) maka dapat diindikasikan tidak terdapat multicollinearity dan Singularity. Hasil dari pengolahan menunjukkan bahwa nilai determinant of sample covariance matrix sebesar $4.5737 \mathrm{e}-019$ melebihi nol. Ini berarti ada multicollinearity, namun dalam model ini hanya ada satu independen maka tidak ada multicollinearity.

\section{Analisis Hipotesis}

Hasil uji hipotesis penelitian ini dapat dilihat dengan nilai regression weight pada kolom CR yang identik dengan nilai t-hitung dihasilkan dari program AMOS. Nilai CR dibandingkan dengan nilai kritisnya yaitu $\pm 1,96$. Jika nilai CR hasil pengolahan lebih besar dari nilai kritisnya, maka hipotesis yang diajukan diterima. Sebaliknya jika CR lebih kecil dari nilai kritisnya, maka hipotesis akan ditolak.

Tabel.1.1

Hasil Uji Regression Weights

\begin{tabular}{|ll|c|c|c|c|}
\hline \multicolumn{1}{|c|}{ Variabel } & Estimate & CR & P & Keterangan \\
\hline $\begin{array}{l}\text { Partisipasi Penyusunan anggaran } \\
\text { K epuasan Kerja }\end{array}$ & $\longrightarrow$ & 0.147 & 2.448 & $\mathbf{0 . 0 1 4}$ & Signifikan \\
\hline $\begin{array}{l}\text { Partisipasi Penyusunan anggaran } \\
\text { Kinerja Karyawan }\end{array}$ & $\rightarrow$ & 0.216 & 2.648 & $\mathbf{0 . 0 0 8}$ & Signifikan \\
\hline Partisipasi Penyusunan anggaran $\longrightarrow$ JRI & 0.414 & 2.873 & $\mathbf{0 . 0 0 4}$ & Signifikan \\
\hline PA $\longrightarrow$ JR $\longrightarrow$ Kinerja karyawan & 0.879 & 6.067 & $\mathbf{0 . 0 0 0}$ & Signifikan \\
\hline PA $\longrightarrow$ JR $\longrightarrow$ Kepuasan Kerja & 0.987 & 6.976 & $\mathbf{0 . 0 0 0}$ & Signifikan \\
\hline
\end{tabular}

Tabel 1.2.

Hasil Uji Direct and Indirect Effects

\begin{tabular}{|c|c|c|}
\hline Variabel & $\begin{array}{l}\text { Hubungan } \\
\text { langsung }\end{array}$ & Hubungan Tidak langsung \\
\hline $\begin{array}{l}\text { Partisipasi Penyusunan anggaran } \\
\text { K epuasan Kerja }\end{array}$ & 0.147 & 0.408 \\
\hline $\begin{array}{l}\text { Partisipasi Penyusunan anggaran } \longrightarrow \\
\text { Kinerja Karyawan }\end{array}$ & 0.21 & 0.363 \\
\hline Partisipasi Penyusunan anggaran $\rightarrow$ JRI & 0.414 & 0.000 \\
\hline $\mathrm{PA} \rightarrow \mathrm{JR} \longrightarrow$ Kinerja karyawan & 0.879 & 0.000 \\
\hline $\mathrm{PA} \rightarrow \mathrm{JRH} \longrightarrow$ Kepuasan Kerja & 0.987 & 0.000 \\
\hline
\end{tabular}


Hipotesis pertama menyatakan penyusunan anggaran dan kepuasan kerja mempunyai hubungan yang positif terdukung. Didalam tabel regression weights nilai critical ratio (CR) berada diatas nilai \pm 1.96 (CR: 2.448 ) dan nilai $P$ valuenya 0.014 . Hasil ini menunjukkan bahwa adanya pengaruh positif dan signifikan antara partisipasi penyusunan anggran dengan kepuasan kerja. Hal ini juga menunjukkan semakin tinggi tingkat partisipasi penyusunan anggaran semakin tinggi pula tingkat kepuasaan kerja. Hubungan langsung antara variabel partisipasi penyusunan anggaran terhadap kepuasan kerja adalah 0.147 dan hubungan tidak langsungnya sangat kuat yaitu 0.408 . artinya variabel partisipasi penyusunan anggaran memiliki pengaruh tidak langsung kepada variabel kepuasan kerja.

Hipotesis kedua terdukung dilihat dari nilai critical ratio (CR) berada diatas nilai \pm 1.96 (CR: 2.648) dan nilai $P$ valuenya 0.008 . Hasil ini menunjukkan bahwa adanya pengaruh positif dan signifikan antara partisipasi penyusunan anggaran dengan kinerja karyawan. Semakin tinggi tingkat partisipasi penyusunan anggaran samkin tingggi pula tingkat kinerja karyawan. Hubungan langsung antara variabel partisipasi penyusunan anggraran terhadap kinerja karyawan adalah 0.216 dan 0.363 hubungan tidak langsungnya lebih kuat. Artinya bahwa variabel partisipasi penyusunan anggaran memiliki pengaruh tidak langsung terhadap variabel kinerja karyawan.

Hipotesis ketiga ini membuktikan bahwa semakin tinggi tingkat partisipasi penyusunan anggaran semakin besar juga informasi yang dibutuhkan dalam mencapai tujuan perusahaan. Dilihat dari nilai nilai critical ratio (CR) berada diatas nilai \pm 1.96 (CR: 2.873 ) dan nilai $\mathrm{P}$ valuenya 0.004 . Hasil menunjukkan bahwa adanya pengaruh positif dan signifikan antara partisipasi penyusunan anggaran dengan job relevant information. Dalam hal ini terjadi suatu proses pengolahan interaksi mulai dari adanya interaksi antara atasan dan bawahan, yang selanjutnya terjadi hubungan timbal balik komunikasi yang aktif antara atasan dan bawahan (komunikasi ke atas). Akan tetapi dalam hubungan langsiung antara variabel partisipasi penyusunan anggaran terhadap job relevant information sangat kuat yaitu 0.414 sedangkan hubungan tidak langsung lemah yaitu 0,000.artinya variabel partisipasi penyusunan anggaran memiliki pengaruh langsung terhadap job relevant information.
Hipotesis keempat menyatakan partisipasi penyusunan anggaran terhadap kepuasan kerja melalui varibel intervening job relevant information menghasilkan hasil positif dan signifikan dapat dilihat dari nilai nilai critical ratio (CR) berada diatas nilai \pm 1.96 (CR: 6.976) dan nilai $P$ valuenya 0.000 . Sedangkan untuk hubungan langsung antara variabel partisipasi penyusunan anggaran melalui varibel intervening job relevant information terhadap kepuasan kerja sangat kuat yang ditunjukkan dengan nilai 0.987 dan hubungan tidak langsung lemah yaitu 0.000. Artinya varibel partisipasi penyusunan anggaran memiliki hubungan langsung melalui job relevant information terhadap kepuasan kerja.

Hipotesis kelima menyatakan partisipasi penyusunan anggaran dan kinerja karyawan melalui variabel intervening job relevant information mempunyai hubungan positif dan signifikan. Dalam tabel nilai nilai critical ratio (CR) berada diatas nilai \pm 1.96 (CR: 6.067) dan nilai $\mathrm{P}$ valuenya 0.000 . Hasil ini menunjukkan bahwa adanya pengaruh positif dan signifikan partisipasi penyusunan anggaran terhadap kinerja karyawan melalui job relevant information. Dalam hubungan langsung antara variabel partisipasi penyusunan anggaran melalui varibel job relevant information terhadap kinerja karyawan sangat kuat yaitu 0.879 dan hubungan tidak langsung lemah yaitu 0.000 . Artinya varibel partisipasi penyusunan anggaran memiliki pengaruh langsung melalui varibel Job relevant information terhadap kinerja karyawan.

\section{Kesimpulan}

Penelitian ini menguji apakah partisipasi penyusunan anggaran, kepuasan kerja dan kinerja karyawan memiliki hubungan positif baik secara langsung atau tidak langsung melalui varibel Job relevant information. Munculnya ide untuk menguji topik tersebut berawal dari adanya ketidakkonsistenan hasil menguji hubungan antara partisipasi penyusunan anggaran dengan kepuasan kerja serta kinerja karyawan. Dari hasil pengujian ini secara empiris dapat disimpulkan bahwa:

1. Dalam pengujian hubungan partisipasi penyusunan anggaran dan kepuasan kerja menunjukkan bahwa partisipasi penyusunan anggaran berpengaruh positif dan signifikan terhadap kepuasan kerja secara tidak langsung.

2. Pengujian hubungan partisipasi penyusunan anggaran dan kinerja karyawan 
menunjukkan bahwa partisipasi penyusunan anggaran berpengaruh positif dan signifikan terhadap kinerja karyawan secara tidak langsung.

3. Pengujian hubungan partisipasi penyusunan anggaran dan Job relevant information menunjukkan bahwa partisipasi penyusunan anggaran berpengaruh positif dan signifikan terhadap Job relevant information secara langsung.

4. Hubungan partisipasi penyusunan anggaran dan kepuasan kerja melalui Job relevant information menunjukkan adanya pengaruh positif dan signifikan secara langsung.

5. Hubungan partisipasi penyusunan anggaran dan kinerja karyawan melalui Job relevant information menunjukkan adanya pengaruh positif dan signifikan secara langsung.

\section{Implikasi}

Implikasi yang diterapkan dalam penelitian ini adalah:

1. Masih perlu dilakukan penelitian berkaitan dengan pengaruh partisipasi anggaran terhadap kepuasan kerja dan kinerja karyawan. Hal ini didukung oleh hasil penelitian yang masih memberikan hasil yang berbeda-beda. Sehingga dari kajian pustaka dan penelitian-penelitian yang pernah dilakukan dapat disusun hipotesa bahwa partisipasi penyusunan anggaran memiliki pengaruh terhadap kepuasan kerja dan kinerja karyawan.

2. Dapat memperluas hasil penelitianpenelitian terdahulu yang berkaitan dengan variabel pemediasi yang mempengaruhi hubungan antara partisipasi penyusunan anggaran dengan kinerja karyawan.

3. Untuk mengkonfirmasi hasil penelitian yang telah dilakukan oleh penelitian sebelumnya terutama berkenan dengan variabel job relevant information Sebagai pemediasi dan hubungan antara partisipasi penyusunan anggaran, kepuasan kerja dan kinerja karyawan.

\section{Keterbatasan dan Saran Penelitian}

Dalam penelian ini terdapat beberapa keterbatasan yang perlu untuk diperbaiki di penelitian-penelitian selanjutnya, antara lain:

1. Responden yang digunakan dalam penelitian ini hanya berasal dari perusahaan kayu yang berada di Temanggung sehingga harus berhati-hati didalam menggeneralisasikan hasil penelitian ini.
2. Instrument yang digunakan dalam penelitian ini adalah menggunakan self rating (penilaian pada diri sendiri) sehingga terdapat kemungkinan terjadi pengisian yang bias oleh responden, yaitu adanya kecenderungan responden untuk menilai kinerjanya lebih tinggi dari yang seharusnya. Hal ini mungkin berbeda seandainya digunakan instrument dengan superior rating. Kedua konsep tersebut memiliki sudut pandang berbeda yang mungkin mempengaruhi perolehan hasil.

3. Pengunaan metode survey dalam penelitian ini mengakibatkan tidak terdapat dilakukan kontrol atas jawaban responden. Persepsi responden belum tentu memperlihatkan keadaan yang sesungguhnya karena peneliti tidak melakukan wawancara dan tidak terlibat langsung dalam aktifitas karyawan.

\section{DAFTAR PUSTAKA}

Abriyani, Puspaningsih, Pengaruh Partisipasi Penyusunan anggaran terhadap kepuasan kerja dan kinerja Manajer: Role Ambiguty Sebagai variabel antara, Thesis, Program Pasca Sarjana Universitas Gadjah Mada, Yogyakarta, 1998.

Anthony, R,N. dan V Govindarajan.2003. Management Control System, Edisi 11, McGraw Hill, New York.

Barry Cushway, Manajemen Sumber daya Manusia (Perencanaan, Analisis Kinerja, Penghargaan), PT.Elex Media Komputindo Kelompok Gramedia, Jakarta, 1996.

Ferdinand, A. 2005. Structural Equation modeling dalam penelitian ManajemenI.Edisi ketiga. Badan penerbit Universitas Diponegoro.

Gul.A.,J.S.L. Tsui,S.C.C. Fong, dan H.Y.L. Kwow 1995,decentralization as a moderating Factor in budgetary participation performance relationship:Some Hongkong Evidence, Accounting and Business research, Vol.25.

Indriani, Mirna, Pengaruh Partisipasi dalam Penyusunan Anggaran terhadap Prestasi kerja dan Kepuasan Kerja pada Aparat Pemerintah tingkat 1 provinsi Daerah Istimewa Aceh, Tesis, Program Pasca Sarjana Universitas Gadjah Mada, Yogyakarta, 1993.

Luthans,Fred, 1998, Organizational Behavior, Eight Edition.New York;McGraw-Hill co.

Marsudi dan Ghozali, Pengaruh Partisipasi Penganggaran, Job relevant Information 
dan Volatilitas lingkungan terhadap Kinerja Manajerial pada perusahaan Manufaktur di Indonesia, JAAI volume 5 no 2 Desember 2000.

Mulyadi, Akuntansi Manajemen: Konsep, Manfaat dan Rekayasa, BP STIE YKPN, Yogyakarta, 1993.

Nunnaly, D.,1978, Psychometric Theory, New York, MC Graw-Hill.

Riyadi, S.2000. Motivasi dan Pelimpahan Wewenang Sebagai varibel Moderating dalam Hubungan Antara Partisipasi Penyusunan Anggaran dan Kinerja Manajerial, Jurnal Riset Akuntansi Indonesia, Vol.3, No.3 Juli;134-150.

Rosidi,2000. Partisipasi dalam Penganggaran dan Prestasi Manajer: Pengaruh komitmen Organisasi dan Informasi Job relevant. Jurnal Ekonomi dan Manajemen, Vol.1 Juni;1-15.

Siegel, Gary \& Helene Ramanauskas Marconi, Behavioral Accounting, South Western

Sinurya, Chandra.2008. Pengaruh Partisipasi Penyusunan Anggaran terhadap Kinerja manajer: Peran kecukupan anggaran dan $J o b$ relevant information Sebagai Varibel Intervening. Thesis. Program Pasca Sarjana Universitas Gadjah Mada.
Sekaran,U.2000.Research Methods For Business. 3 Ed., New York: John Wiley \& Sons, Inc.

Solimun, 2002. Structural Equation Modeling, Lisrel dan Amos.Makalah.Program Pasca Sarjana Universitas Brawijaya Malang.

Supriyono,2004. Pengaruh varibel intervening Kecukupan Anggaran dan komitmen organisi terhdap Hubungan antara partisipasi penganggaran dan kinerja Manajer di Indonesia. Jurnal ekonomi dan Bisnis Indonesia, Vol.19, No.3;282-298

Yusfaningrum.K,dam I. Ghozali.2005. Analisis Pengaruh Partisipasi Anggaran terhadap kinerja Manajerial melalui Komitmen tujuan Anggaran dan Job relevant Information (JRI) Sebagai Variabel intervening. Simposium Nasional Akuntansi VIII, Solo, 15-16 September: 656-666.

Vebyana, Siregar, 2003. Hubungan Partisipasi Penyusunan Anggaran dengan informasi Job relevant serta pengaruhnya terhadap kepuasan kerja dan kinerja Manajerial dilingkungan Pemerintah Yogyakarta, Tesis, program pasca Sarjana Universitas gadjah Mada, Yogyakarta. 